\title{
PERILAKU HIDUP BERSIH DAN SEHAT (PHBS) SISWA/SISWI DI SEKOLAH MENENGAH PERTAMA NEGERI (SMPN)
}

\author{
Sri Hendrawati ${ }^{\left.1^{*}\right)}$, Udin Rosidin ${ }^{2}$, Santi Astiani ${ }^{3}$ \\ ${ }^{1}$ Departemen Keperawatan Anak, Fakultas Keperawatan, Universitas Padjadjaran \\ ${ }^{2}$ Departemen Keperawatan Komunitas, Fakultas Keperawatan, Universitas Padjadjaran, \\ ${ }^{3}$ Mahasiswa Fakultas Keperawatan, Universitas Padjadjaran, \\ E-mail: ${ }^{*}$ sri.hendrawati@unpad.ac.id
}

\begin{abstract}
Abstrak
Perilaku hidup bersih dan sehat di lingkungan sekolah merupakan sekumpulan perilaku yang dipraktikan oleh peserta didik, guru, dan masyarakat lingkungan sekolah sebagai hasil pembelajaran. Permasalahan yang muncul di sekolah menengah pertama negeri menunjukan siswa/siswi tidak melakukan PHBS seperti jarang melakukan cuci tangan dengan air mengalir dan sabun, jarang menggunakan jamban sehat, jarang membuang sampah pada tempatnya sehingga terjadi beberapa kasus kejadian penyakit dseperti diare, cacingan, typoid, dan maag. Penelitian ini bertujuan untuk mengidentifikasi gambaran PHBS pada siswa/siswi di sekolah menengah pertama negeri. Penelitian ini menggunakan desain penelitian deskriptif kuantitatif. Populasi pada penelitian ini adalah siswa/siswi di SMPN 3 dan SMPN 4 di Wilayah Kerja Puskesmas Guntur Garut yang berjumlah 1458. Teknik pengambilan sempel menggunakan stratified random sampling sehingga didapatkan 317 orang. Penelitian ini menggunakan intrumen kuesioner PHBS di sekolah. Data dianalisis secara univariat dengan menggunakan nilai mean dan disajikan dalam distribusi frekuensi. Hasil penelitian menunjukan bahwa setengah dari responden yaitu sebanyak 160 (50,5\%) siswa/siswi sudah berperilaku baik dalam berperilaku hidup bersih dan sehat, dan hampir setengah responden yaitu sebanyak 157 (49,5\%) siswa/siswi masih berperilaku buruk dalam berperilaku hidup bersih dan sehat. PHBS pada siswa/siswi ini harus lebih ditingkatkan lagi dengan cara pemberdayaan UKS bekerjasama dengan perawat yang ada di puskesmas terdekat dengan melakukan penyuluhan tentang PHBS.
\end{abstract}

Kata kunci: Pelaksanaan PHBS, PHBS, sekolah.

\begin{abstract}
Clean and healthy life behaviour in school environment is an accumulation of behaviours which are practiced by students, teachers, and community as a result of learning. Problems which arose in junior high school showed that students did not do clean and healthy life behaviour such as rarely washing their hands with running water and soap, rarely using healthy toilets, rarely throwing garbage in the right places so that there were several cases of diseases such as diarrhea, intestinal worms, typoid, and peptic ulcer.This research aimed to identify the description of clean and healthy life behaviour in SMPN 3 and SMPN 4 Garut in the area of Guntur Community Health Centre. The research method used descriptive quantitative. The population in this research was students of SMPN 3 and SMPN 4 Garut, with the total of 1458. The sampling technique used stratified random sampling so that 317 people were obtained. This research used the clean and healthy life behaviour questionnaire instrument in schools. Data were analyzed univariately using mean values and presented in a frequency distribution. The results showed half of the respondents were $160(50.5 \%)$ of students had behaved well in behaving clean and healthy, and almost half the respondents were 157 (49.5\%) students still behaved poorly in the behavior of clean and healthy. PHBS for these students must be further improved by empowering School Health Unit in collaboration with the nurses at the nearest community health centre by conducting education about clean and healthy life behaviour.
\end{abstract}

Keywords: Implementation of PHBS, PHBS, Schools. 


\section{Pendahuluan}

Perilaku hidup bersih dan sehat (PHBS) adalah suatu upaya untuk menciptakan lingkungan sehat untuk memperhatikan setiap orang melakukan perilaku kesehatan anggota keluarga atau individu sehingga dapat berperan aktif dalam setiap kegiatan-kegiatan kesehatan di masyarakat (Sondakh, Joseph, \& Koem, 2015). Program PHBS dikembangkan berdasarkan peraturan Menteri Kesehatan Republik Indonesia Nomor 2269/MENKES/PER/XI/2011. Didalam pedoman ini ada beberapa tatanan yang mengatur upaya peningkatan PHBS, diantaranya tatanan rumah tangga, tatanan institusi kesehatan, tatanan tempat-tempat umum, tatanan tempat kerja, dan tatanan institusi pendidikan.

PHBS di institusi pendidikan adalah sekumpulan perilaku yang dipraktikan oleh peserta didik, guru, dan masyarakat lingkungan sekolah atas dasar kesadaran sebagai hasil pembelajaran, sehingga secara mandiri mampu mencegah penyakit, meningkatkan kesehatannya, serta berperan aktif dalam mewujudkan lingkungan sehat (Fahruzi \& Devis, 2017). Secara nasional ada 8 indikator yang dipakai sebagai ukuran untuk menilai dan mengetahui PHBS di tatanan institusi pendidikan mencakup mencuci tangan dengan air yang mengalir dan menggunakan sabun, mengkonsumsi jajan sehat di kantin sekolah, menggunakan jamban yang bersih dan sehat, olahraga yang teratur dan terukur, memberantas jentik nyamuk, tidak merokok di sekolah, membuang sampah pada tempatnya, menimbang berat badan dan mengukur tinggi badan (Dewi, Yudi, \& Gabur, 2017).

Indikator-indikator daam rangka meningkatkan perilaku hidup sehat dan bersih harus dilakukan dengan baik agar tercipta perilaku sehat di lingkungan sekolah. Sekolah merupakan salah satu institusi pendidikan yang menjadi sasaran PHBS, sehingga dapat mewujudkan generasi anak sehat dan bisa menerapkan perilaku tersebut menjadi lebih baik. Sekolah selain sebagai tempat belajar bagi anak merupakan sarana tempat bersosialisasi dengan teman sebaya, guru, dan pembina Usaha Kesehatan Sekolah (UKS) (Ispriantari, Priasmoro \& Mashitah, 2017).

Menurut Departemen Kesehatan Republik Indonesia (2010), melihat secara nasional yang telah memenuhi kriteria PHBS sekolah yang baik tahun 2015 sebesar 40\%, diharapkan penduduk Indonesia memenuhi kriteria PHBS di sekolah. Profil Kesehatan Indonesia tahun 2015 menyajikan data bahwa yang berperilaku hidup bersih dan sehat di lingkungan sekolah terdapat sebanyak $68 \%$. Sedangkan menurut keterangan Ronosulistyo dan Ina (2009), pencapaian program PHBS di Provinsi Jawa Barat tahun 2007 masih rendah yaitu $34,8 \%$. Sementara itu berdasarkan data Dinas Kesehatan Kabupaten Garut menunjukkan bahwa pada tahun 2018, jumlah yang berperilaku hidup bersih dan sehat (PHBS) di sekolah sebanyak $37,25 \%$ sementara target yang ditetapkan di tahun 2018 sebanyak 50\%. Hal ini menunjukkan bahwa masih rendahnya perilaku hidup bersih dan sehat di lingkungan sekolah yang ada di Kabupaten Garut belum tercapai. Penelitian lain menunjukkan banyak faktor yang mengakibatkan siswa/siswi tidak melaksanakan PHBS.

Menurut terori Lawrence Green (1980) dalam buku Notoatmodjo (2014) menyatakan bahwa perilaku seseorang termasuk kedalam pelaksanakan PHBS serta dapat dipengaruhi oleh tiga faktor. Faktor yang pertama yaitu faktor predisposing yang terwujud dalam pengetahuan, sikap, kepercayaan, keyakinan, dan nilai-nilai. Faktor kedua yaitu faktor enabling yang meliputi faktor pendukung yang terwujud dalam tersedia atau tidak tersedia fasilitas atau sarana dan akses. Faktor yang ketiga faktor reinforcing yaitu faktor pendorong yang terwujud dalam sikap dan perilaku.

Menurut penelitian yang dilakukan oleh Yulianti (2015), menunjukkan bahwa siswa/siswi yang tidak melaksanakan perilaku hidup bersih dan sehat disebabkan oleh adanya beberapa faktor. Faktor tersebut diantaranya yaitu siswa/siswi memiliki pengetahuan yang rendah tentang PHBS, 
indikator PHBS, manfaat PHBS, dan kerugian tidak PHBS. Dampak dari tidak melaksanakan perilaku hidup bersih dan sehat akan menimbulkan beberapa penyakit diantaranya cacingan, diare, sakit gigi, sakit kulit, gizi buruk dan penyakit lainnya yang pada akhirnya mengakibatkan rendahnya derajat kesehatan Indonesia dan rendahnya kualitas hidup sumber daya Indonesia (Sondakh et al., 2015). Selain itu dampak yang akan dialami oleh anak-anak yang tidak melakukan PHBS di sekolah menurut WHO sebanyak 100.000 anak Indonesia meninggal dunia karena penyakit diare setiap tahunnya. Hal itu diakibatkan oleh jajanan yang tidak sehat atau cuci tangan yang tidak bersih yang tidak dilakukan anak sekolah. Hal ini menunjukkan bahwa anak-anak belum melakukan PHBS. Selain itu masih terdapat anak usia sekolah yang menderita penyakit cacingan karena tidak melakukan cuci tangan menggunakan sabun (Lumongga \& Syahrial, 2013).

Hasil penelitian Lina (2016), menunjukkan bahwa apabila lingkungan sekolah kotor akan mengakibatkan ketidaknyamanan suasana belajar, menurunnya prestasi belajar siswa, serta dapat membuat citra sekolah menjadi buruk. Dampak dari tidak melaksanakan PHBS tersebut menjadi salah satu dasar pemerintah dalam meluncurkan program yang bertujuan untuk mengubah perilaku yang tidak sehat agar menjadi sehat, sehingga diharapkan sekolah dapat terus menjaga lingkungannya agar bersih dan mengajarkan PHBS pada seluruh siswanya (Lolowang, Maramis \& Ratag 2017). Dalam melakukan upaya untuk mencegah dampak tersebut diperlukan kerja sama lintas sektoral dalam hal ini diperlukan peran tenaga kesehatan khususnya perawat.

Peran yang dapat dilakukan oleh perawat antara lain memberikan edukasi tentang PHBS dan cara pencegahan penyakit seperti demam berdarah dengan cara memberantas sarang nyamuk dan membuang sampah pada tempatnya, cara pencegahan diare/cacingan dengan cara cuci tangan sebelum makan dan sesudah makan dan pemilihan jajanan sehat. Edukasi PHBS tersebut diberikan melalui penyuluhan sesuai dengan upaya pemerintah dalam memberikan promosi kesehatan tentang PHBS agar meningkatkan kesadaran siswa/siswi, guru, dan masyarakat sekolah, sehingga terhindar dari penyakit. Hal tersebut membutuhkan kerjasama sekolah dan tenaga kesehatan dalam membangun lingkungan yang sehat (Carolina, \& Lestari, 2016).

Survei awal yang tim peneliti lakukan pada tanggal 14 Desember 2018 berdasarkan data dari Dinas Kesehatan terdapat data PHBS masih ada Puskesmas yang rendah PHBS-nya salah satunya yaitu Puskesmas Guntur, maka dari itu tim peneliti melakukan penelitian di Wilayah Kerja Puskesmas Guntur untuk mengetahui perilaku siswa/siswi setiap harinya di sekolah, kemudian tim peneliti melakukan studi pendahuluan ke Puskesmas Guntur Kabupaten Garut. Setelah melakuan wawancara dengan perawat yang memegang program PHBS, tim peneliti mendapatkan beberapa informasi. Jumlah sekolah yang di pegang di wilayah kerja Puskesmas Guntur yaitu sebanyak 32 sekolah diantaranya ada SD, MI, SMP, MTS, SMA, MA dan SMK. Serta didapatkan data jumlah sekolah ada dua sekolah menengah pertama (SMP) yang menjadi binaan Puskesmas Guntur. SMPN tersebut adalah SMPN 3 dan SMPN 4 Garut. Berdasarkan informasi yang didapat dari puskesmas bahwa SMPN tersebut sudah dilakukan pembinaan untuk melaksanakan PHBS. Hasil wawancara yang dilakukan kepada guru UKS di SMPN 3 dan SMPN 4 Garut bahwa di sekolah tersebut masih banyak yang tidak melakukan kebiasaan tentang 8 indikator PHBS sekolah. Indikator yang sulit dilaksanakan oleh siswa menurut guru UKS adalah mencuci tangan dengan air yang mengalir dan menggunakan sabun, mengkonsumsi jajanan sehat di kantin sekolah, menggunakan jamban yang bersih dan sehat atau membuang sampah pada tempatnya. Apabila ke 8 indikator PHBS tidak terlaksana maka akan terjadi angka kejadian penyakit, penyakit tersebut 
diantaranya diare, cacingan, demam, maag, pusing atau demam berdarah.

Data mengenai angka kejadian penyakit yang didapat dari UKS sekolah SMPN 3 dan SMPN 4 Garut yang tercatat dari bulan September 2018 sampai bulan November 2018 terdiri dari SMPN 3 diare 67 orang, cacingan 41 orang, demam 89 orang, maag 78 orang, pusing 88 orang dan DBD 30 orang. Sementara itu di SMPN 4 Garut diare 59 orang, cacingan 30 orang, demam 68 orang, maag 89 orang, pusing 73 orang dan DBD 38 orang. Berdasarkan data tersebut dapat disimpulkan bahwa tingginya angka kejadian penyakit tersebut kemungkinan besar disebabkan karena ada indikator yang belum dilaksanakan dengan baik. Berdasarkan permasalahan diatas, tim peneliti memandang penting untuk melakukan penelitian mengenai gambaran perilaku hidup bersih dan sehat pada siswa/siswi di Sekolah Menengah Pertama Negeri (SMPN) 3 dan Sekolah Menengah Pertama Negeri (SMPN) 4 Garut Wilayah Kerja Puskesmas Guntur.

\section{Metode Penelitian}

Penelitian ini menggunakan rancangan penelitian deskriptif kuantitatif. Penelitian ini bertujuan untuk mengidentifikasi gambaran perilaku hidup bersih dan sehat pada siswa/siswi di Sekolah Menengah Pertama Negeri (SMPN) 3 dan Sekolah Menengah Pertama Negeri (SMPN) 4 Garut Wilayah Kerja Puskesmas Guntur. Populasi pada penelitian ini adalah 1.458 orang siswa/siswi. Sampel pada penelitian berjumlah 317 orang siswa/siswi menggunakan teknik stratified random sampling yaitu, strata atau subjek seseorang di masyarakat, jenis ini digunakan peneliti untuk mengetahui beberapa variabel pada populasi yang merupakan hal yang penting untuk mencapai sampel yang representatif.

Instrumen yang digunakan pada penelitian ini adalah kuesioner yang diadopsi dengan memodifikasi instrumen PHBS dari penelitian Messakh, Purnawati, dan Panuntun (2019) yang meliputi 8 indikator PHBS di sekolah yaitu 1) mencuci tangan dengan air yang mengalir dan menggunakan sabun, 2) mengkonsumsi jajanan sehat di kantin sekolah, 3) menggunakan jamban yang bersih dan sehat, 4) olahraga yang teratur dan terukur, 5) memberantas jentik nyamuk, 6) tidak merokok di sekolah, 7) menimbang berat badan dan mengukur tinggi badan, dan 8) membuang sampah pada tempatnya. Kuesioner terdiri dari 30 pertanyaan dengan skala pengukuran menggunakan skala likert dengan rentang nilai 1 sampai 4. Uji validitas instrumen dilakukan dengan content validity kepada pakar kemudian construct validity yang dilakukan kepada 30 responden siswa/siswi SMPN 2 Garut wilayah kerja Puskesmas Siliwangi yang memiliki kriteria sama dengan sampel penelitian. Uji validitas menggunakan uji kolerasi Person Product Moment dengan rentang nilai 0,42-0,891. Sedangkan uji reliabilitas instrumen ini menggunakan rumus Alpha Cronbach dengan nilai hasil uji $>0,809$ sehingga instrumen dinyatakan reliabel.

Penelitian ini sudah mendapat izin dari Komite Etik Penelitian Kesehatan Universitas Padjadjaran dengan nomor 738/UN6.KEP/EC/2019. Proses pengumpulan data dilakukan tim peneliti dengan melaksanakan informed consent terlebih dahulu dan memegang teguh prindip etika penelitian. Setelah data terkumpul kemudian diolah dan dianalisis menggunakan nilai mean karena data terdistribusi normal. Perilaku hidup bersih dan sehat dikelompokan menjadi 2 kategori dengan menggunakan standar skor sebagai berikut: 1) PHBS dikategorikan baik apabila total skor jawaban $\geq$ nilai mean, dan 2) PHBS dikategorikan buruk jika total skor jawaban < nilai mean.

\section{Hasil dan Pembahasan}

Berikut ini merupakan tabel hasil penelitian yang meliputi karakteristik responden (tabel 1), perilaku hidup bersih dan sehat secara umum (tabel 2), dan perilaku hidup bersih dan sehat untuk setiap indikator (tabel 3). 
Tabel 1

Karakteristik Responden

\begin{tabular}{lcc}
\hline \multicolumn{1}{c}{ Karakteristik } & \multicolumn{2}{c}{ Jumlah } \\
\hline Jenis Kelamin & $\boldsymbol{f}$ & $\mathbf{\%}$ \\
Laki-laki & 85 & \\
Perempuan & 232 & 26,8 \\
Kelas & & 73,2 \\
VII & 159 & 50,2 \\
VIII & 158 & 49,8 \\
\hline
\end{tabular}

Tabel 1 diatas menunjukkan hasil penelitian yang dilakukan di Sekolah Menengah Pertama Negeri wilayah kerja Puskesmas Guntur yaitu sebagian besar responden berjenis kelamin perempuan sebanyak 232 orang $(73,2 \%)$ dan sebanyak $159(50,2 \%)$ merupakan kelas VII dan sebanyak 158 orang $(49,8 \%)$ merupakan kelas VIII.

Tabel 2

Distribusi Frekuensi Perilaku Hidup Bersih dan Sehat Siswa/Siswi di Sekolah Menengah Pertama Negeri $(n=317)$

\begin{tabular}{lcc}
\hline \multirow{2}{*}{$\begin{array}{c}\text { Perilaku Hidup Bersih } \\
\text { dan Sehat }\end{array}$} & \multicolumn{2}{c}{ Jumlah } \\
\cline { 2 - 3 } & 160 & \% \\
\hline Baik & 157 & 50,5 \\
Buruk & & 49,5 \\
\hline
\end{tabular}

Tabel 2 menunjukkan bahwa setengah dari responden yaitu sebanyak 160 orang (50,5\%) siswa/siswi berperilaku baik dalam berperilaku hidup bersih dan sehat, dan hampir setengah responden yaitu sebanyak 157 orang $(49,5 \%)$ siswa/siswi berperilaku buruk dalam berperilaku hidup bersih dan sehat.

Tabel 3

Distribusi Frekuensi Perilaku Hidup Bersih dan Sehat Siswa/Siswi di Sekolah Menengah Pertama Negeri untuk Setiap Indikator $(n=317)$

\begin{tabular}{|c|c|c|c|c|}
\hline \multirow[t]{2}{*}{ No } & \multirow{2}{*}{$\begin{array}{c}\text { Indikator Perilaku Hidup } \\
\text { Bersih } \\
\text { dan Sehat }\end{array}$} & \multirow{2}{*}{$\begin{array}{c}\text { Perilaku } \\
\text { Hidup Bersih } \\
\text { dan Sehat }\end{array}$} & \multicolumn{2}{|c|}{ Jumlah } \\
\hline & & & $f$ & $\%$ \\
\hline \multirow[t]{2}{*}{1.} & Perilaku mencuci tangan dengan & Baik & 155 & 48,9 \\
\hline & $\begin{array}{l}\text { air yang mengalir dan } \\
\text { menggunakan sabun }\end{array}$ & Buruk & 162 & 51,1 \\
\hline \multirow[t]{2}{*}{2.} & Perilaku mengkonsumsi jajanan & Baik & 152 & 47,9 \\
\hline & sehat & Buruk & 165 & 52,1 \\
\hline \multirow[t]{2}{*}{3.} & Perilaku menggunakan jamban & Baik & 226 & 71,3 \\
\hline & bersih dan sehat & Buruk & 91 & 28,7 \\
\hline \multirow[t]{2}{*}{4.} & Perilaku olahraga yang teratur dan & Baik & 188 & 59,3 \\
\hline & terukur & Buruk & 129 & 40,7 \\
\hline \multirow[t]{2}{*}{5.} & memberantas & Baik & 163 & 51,4 \\
\hline & nyamuk & Buruk & 154 & 48,6 \\
\hline \multirow[t]{2}{*}{6.} & Perilaku tidak merokok di sekolah & Baik & 175 & 55,2 \\
\hline & & Buruk & 142 & 44,8 \\
\hline \multirow[t]{2}{*}{7.} & Perilaku menimbang berat badan & Baik & 241 & 76,0 \\
\hline & dan mengukur tinggi badan & Buruk & 76 & 24,0 \\
\hline \multirow[t]{2}{*}{8.} & Perilaku membuang sampah pada & Baik & 223 & 70,3 \\
\hline & tempatnya & Buruk & 94 & 39,7 \\
\hline
\end{tabular}


Tabel 3 menunjukkan PHBS untuk setiap indikator yang mencakup 8 indikator. Indikator pertama yaitu perilaku mencuci tangan dengan air yang mengalir dan menggunakan sabun menunjukkan bahwa hampir setengahnya yaitu sebanyak 155 orang $(48,9 \%)$ siswa/siswi berperilaku baik dalam cuci tangan, dan sebagian besar yaitu sebanyak 162 orang $(51,1 \%)$ siswa/siswi berperilaku buruk dalam cuci tangan. Indikator kedua yaitu perilaku mengkonsumsi jajanan sehat menunjukkan bahwa hampir setengahnya yaitu sebanyak 152 orang $(47,9 \%)$ siswa/siswi berperilaku baik dalam mengkonsumsi jajanan sehat, dan sebagian besar yaitu sebanyak 165 orang $(52,1 \%)$ siswa/siswi berperilaku buruk dalam jajan sehat dikantin sekolah. Indikator ketiga yaitu perilaku menggunakan jamban bersih dan sehat menunjukkan bahwa sebagian besar yaitu sebanyak 226 orang $(71,3 \%)$ siswa/siswi berperilaku baik dalam menggunakan jamban sehat, dan hampir setengahnya yaitu sebanyak 91 orang $(28,7 \%)$ siswa/siswi berperilaku buruk dalam menggunakan jamban. Indikator keempat yaitu perilaku olahraga yang teratur dan terukur menunjukkan sebagian besar yaitu sebanyak 188 orang $(59,3 \%)$ siswa/siswi berperilaku baik dalam olahraga yang teratur dan terukur, dan hampir setengahnya yaitu sebanyak 129 orang $(40,7 \%)$ siswa/siswi berperilaku buruk dalam olahraga teratur dan terukur.

Indikator kelima yaitu perilaku memberantas jentik nyamuk menunjukkan bahwa sebagian besar yaitu sebanyak 163 orang $(51,4 \%)$ siswa/siswi berperilaku baik dalam memberanas jentik nyamuk, dan hampir setengahnya yaitu sebanyak 154 orang $(48,6 \%)$ siswa/siswi berperilaku buruk dalam memberantas jentik nyamuk. Indikator keenam yaitu perilaku tidak merokok di sekolah menunjukkan bahwa sebagian besar yaitu sebanyak 175 orang $(55,2 \%)$ siswa/siswi berperilaku baik yaitu tidak merokok di lingkungan sekolah, dan hampir setengahnya yaitu sebanyak 142 orang $(44,8 \%)$ siswa/siswi berperlaku buruk yaitu merokok di lingkungan sekolah. Indikator ketujuh yaitu perilaku menimbang berat badan dan mengukur tinggi badan menunjukkan bahwa hampir seluruhnya yaitu sebanyak 241 orang $(76,0 \%)$ siswa/siswi berperilaku baik dalam menimbang berat badan dan mengukur tinggi badan, dan sebagian kecil yaitu sebanyak 76 orang $(24,0 \%)$ siswa/siswi berperilaku buruk dalam menimbang berat badan dan mengukur tinggi badan. Adapun untuk indikator kedelapan yaitu perilaku membuang sampah pada tempatnya menunjukkan bahwa sebagian besar yaitu sebanyak 223 orang (70,3\%) siswa/siswi berperilaku baik dalam membuang sampah pada tempatnya, dan hampir setengahnya yaitu sebanyak 94 orang $(29,7 \%)$ siswa/siswi berperilaku buruk dalam membuang sampah pada tempatnya.

\section{Hasil Pengukuran Perilaku Hidup Bersih dan Sehat di Sekolah}

Hasil penelitian mengenai perilaku hidup bersih dan sehat di sekolah menunjukkan bahwa setengah dari responden sudah berperilaku baik dalam berperilaku hidup bersih dan sehat, dan hampir setengah responden masih berperilaku buruk dalam berperilaku hidup bersih dan sehat. Sehingga hal ini harus menjadi perhatian penting sekolah dan usaha kesehatan sekolah yang ada dibawah bimbingan puskesmas. Hasil penelitian ini walaupun setengahnya dari responden sudah berperilaku baik tetapi masih terdapat hampir setengahnya responden yang masih berperilaku buruk sehingga harus segera ditindaklanjuti.

Hal ini sejalan dengan penelitian yang dilakukan Sulastri, Purna, dan Suyasa (2013) yang mendapatkan hasil bahwa siswa/siswi yang berperilaku baik dalam PHBS sebanyak $42,2 \%$ dan siswa/siswi yang berperilaku buruk sebanyak 57,8\%. Hal ini disebabkan karena adanya faktor internal siswa yaitu kurangnya kemauan untuk berperilaku hidup bersih dan sehat. Adanya fasilitas seperti air yang mengalir dan sabun tidak mereka gunakan untuk mencuci tangan sebelum mengambil/membeli makanan di kantin 
sekolah. Hal ini dapat disebabkan karena keadaan sanitasi seperti WC berbau dan kurang bersih sehingga walaupun tersedia fasilitas cuci tangan tetapi ada faktor yang menghambat juga, selain itu masih terdapat beberapa siswa/siswi yang membuang sampah begitu saja di depan kantin walaupun sudah tersedia tempat sampah karena tempat sampahnya jauh atau siswanya yang malas berpindah tempat karena sudah berkumpul dengan temannya. PHBS merupakan cerminan pola hidup keluarga yang senantiasa memerhatikan dan menjaga kesehatan seluruh anggota keluarga. Mencegah lebih baik dari pada mengobati inilah yang menjadi dasar untuk melaksanakan PHBS (Simbolon, \& Simorangkir, 2018).

Hasil penelitian ini juga sejalan dengan penelitian Lolowang, Maramis, dan Ratag (2017), yang menyatakan bahwa setengahnya siswa/siswi memilik perilaku yang baik $(50,9 \%)$ dan hampir setengahnya siswa/siswi memiliki perilaku yang buruk $(44,4 \%)$ dalam hal PHBS di sekolah. Hal ini dapat disebabkan karena terdapat hubungan antara tingkat pengetahuan dengan pelaksanaan PHBS. PHBS di sekolah merupakan sekumpulan perilaku yang di praktikan oleh siswa/siswi, guru, dan masyarakat yang ada di lingkungan sekolah atas dasar kesadaran sebagai hasil pembelajaran sehingga secara mandiri mampu mencegah penyakit, meningkatkan kesehatannya serta berperan aktif dalam mewujudkan lingkungan sehat dan bersih (Wokas, Sulastri, \& Kartinah, 2018). Konsep perilaku yang dikembangkan Becker, merupakan konsep perilaku sehat. Bahwa perilaku sehat tersebut terbagi menjadi tiga domain, yaitu pengetahuan terhadap kesehatan, sikap untuk merespon tindakan kesehatan, dan praktik domain ini bermanfaat untuk mengetahui seberapa besar tingkat perilaku sehat setiap individu (Notoatmodjo, 2010).

Salah satu cara membentuk perilaku siswa/siswi adalah dengan cara membiasakan diri untuk berperilaku seperti yang diharapkan, akhirnya akan terbentuklah perilaku tersebut misalnya membiasakan siswa/siswi untuk mencuci tangan dengan air yang mengalir dan sabun sebelum dan sesudah makan, karena cuci tangan dapat membunuh kuman yang ada di tangan dan masih banyak contoh untuk menggambarkan hal tersebut (Sulastri, Purna, \& Suyasa, 2013). Hasil penelitian ini juga didukung oleh Teori Green yang menyatakan bahwa peran guru merupakan salah satu faktor penguat dalam pembentukan perilaku yaitu faktor yang mendorong untuk bertindak dalam mencapai suatu tujuan yang terwujud dalam peran keluarga terutama orang tua, guru dan petugas kesehatan untuk saling bahu membahu, sehingga tercipta kerjasama yang baik antara pihak rumah dan sekolah yang akan mendukung anak dalam memperoleh pengalaman yang hendak dirancang, lingkungan yang bersifat sebagai pusat anak yang akan mendorong proses belajar melalui penjelajah dan penemuan untuk terjadinya suatu perilaku. Selain itu peranan sekolah juga tidak kalah penting dalam membuat suatu kebijakan yang bisa meningkatkan peran guru terhadap tindakan PHBS pada siswanya. Hal lain yang mungkin juga bisa dilakukan adalah dengan memberikan informasi PHBS kedalam kurikulum pembelajaran di sekolah.

Upaya untuk siswa/siswi yang berperilaku sudah baik harus bisa mempertahankan perilaku bersih dan sehat di sekolah dengan tidak membuang sampah sembarangan, tidak merokok di sekolah, memberantas nyamuk, menggunakan jamban sehat, olahraga secara teratur dan terukur, sering melakukan menimbang berat badan dan mengukur tinggi badan setiap 6 bulan sekali, dan upaya untuk siswa/siswi yang berperilaku buruk harus bisa meningkatkan lagi perilaku hidup bersih dan sehat agar tidak terjadinya pencemaran kuman yang akan menyebabkan penyakit serta siswa/sisiwi tersebut harus sering diberi pembelajaran atau penyuluhan dari puskesmas. Serta peran guru dalam memberikan pembelajaran terkait perilaku 
hidup bersih dan sehat, selain itu pihak sekolah perlu melakukan penyuluhan peraturan seperti kebiasaan terkait PHBS karena sudah ada fasilitas yang memadai seperti tempat cuci tangan, tempat sampah, toilet, UKS, kantin sekolah, lapang olahrag, alat pengukuran $\mathrm{TB}$ dan penimbang $\mathrm{BB}$.

\section{Hasil Pengukuran Perilaku Hidup Bersih dan Sehat di Sekolah untuk Setiap Indikator}

Perilaku hidup bersih dan sehat di tatanan sekolah ini terdiri dari 8 indikator. Dari kedelapan indikator tersebut sudah terdapat 6 indikator yang memiliki perilaku baik tetapi harus terus dipertahankan dan diberikan penguatan baik oleh pihak sekolah maupun puskesmas yaitu perilaku menggunakan jamban bersih dan sehat, perilaku olahraga yang teratur dan terukur, perilaku memberantas jentik nyamuk, perilaku tidak merokok di sekolah, perilaku menimbang berat badan dan mengukur tinggi badan, dan perilaku membuang sampah pada tempatnya. Adapun untuk indikator perilaku mencuci tangan dengan air yang mengalir dan menggunakan sabun dan perilaku mengkonsumsi jajanan sehat siswa/siswi masih banyak yang berperilaku buruk.

Indikator pertama yaitu perilaku mencuci tangan dengan air yang mengalir dan menggunakan sabun menunjukkan bahwa hampir setengahnya siswa/siswi berperilaku baik dalam cuci tangan, dan sebagian besar siswa/siswi masih berperilaku buruk dalam cuci tangan. Terdapatnya sarana cuci tangan seperti adanya wastafel di setiap depan kelas dengan disertai air yang mengalir dan didukung oleh tersedianya sabun untuk mencuci tangan, hal ini mungkin yang menyebabkan siswa/siswi di sekolah memiliki perilaku cuci tangan yang baik. Berbeda halnya dengan sekolah yang memiliki sarana untuk cuci tangan yang tidak lengkap yaitu sudah terdapat wastafel di setiap depan kelas tetapi kran airnya sudah pada rusak dan tidak terdapat air mengalir mungkin hal ini yang bisa menyebabkan perilaku siswa/siswi di sekolah memiliki perilaku cuci tangan yang buruk. Perilaku cuci tangan adalah kegiatan yang dilakukan seseorang dalam membersihkan bagian tangan dengan tujuan untuk membersihkan tangan dari kotoran dan membunuh kuman penyebab penyakit yang merugikan kesehatan manusia (Rahayu, Muhlisin \& Sudaryanto, 2016). Perilaku cuci tangan ini sangat penting dilakukan karena merupakan salah satu tindakan yang penting untuk mencegah masuknya mikroba kedalam tubuh (Paulik et al., 2014).

Indikator kedua yaitu perilaku mengkonsumsi jajanan sehat menunjukkan bahwa hampir setengahnya siswa/siswi berperilaku baik dalam mengkonsumsi jajanan sehat, dan sebagian besar siswa/siswi berperilaku buruk dalam jajan sehat dikantin sekolah. Siswa/siswi memiliki perilaku buruk terhadap mengkonsumsi jajanan sehat di kantin sekolah. Kantin sekolah sudah tersedia tetapi masih banyak siswa/siswi yang masih jajan di luar gerbang sekolah seperti jajanan di pinggir jalan yang berjualan secara terbuka. Hal ini sejalan dengan penelitian yang dilakukan Lina (2016), yang mendapatkan hasil bahwa sebagian besar siswa/siswi yaitu sebanyak 56,3\% berperilaku buruk dalam mengkonsumsi jajanan sehat di kantin sekolah. Dikatakan berperilaku buruk karena tidak berfungsinya kantin sekolah sehingga siswa/siswi cenderung jajan di luar lingkungan sekolah. Mengkonsumsi jajanan sehat di kantin sekolah merupakan suatu kebiasaan yang harus ditanamkan pada siswa/siswi. Hal ini sebagai upaya agar siswa/siswi terhindar dari kandungan zat kimia yang terdapat pada makanan yang dijual bebas di luar kantin sekolah. Makanan yang ada dikantin sekolah juga harus diawasi oleh pihak guru, supaya makanan tetap terjaga kebersihan dan kandungan gizinya. Makanan sehat harus mengandung zat yang diperlukan oleh tubuh, sehingga dapat membantu proses pertumbuhan dan perkembanga siswa dengan optimal (Proverawati \& Rahmawati, 2012).

Indikator ketiga yaitu perilaku menggunakan jamban bersih dan sehat 
menunjukkan bahwa sebagian besar siswa/siswi sudah berperilaku baik dalam menggunakan jamban sehat, dan hampir setengahnya siswa/siswi masih berperilaku buruk dalam menggunakan jamban. Siswa/siswi sudah memiliki perilaku baik terhadap menggunakan jamban bersih dan sehat. Sudah tersedianyanya sarana jamban bersih dan sehat sehingga siswa/siswi di sekolah memiliki perilaku baik terhadap jamban bersih dan sehat. Hal ini sejalan dengan penelitian yang dilakukan Solikhah dan Sustini (2013) yang menyatakan bahwa perilaku dikategorikan baik sebesar $67,9 \%$ dalam perilaku menggunakan jamban sehat di sekolah. Meskipun sebagian besar siswa/siswi menggunakan jamban termasuk dalam kriteria baik, namun demikian, presentase anak yang berperilaku kurang dalam menjaga kebersihan dan kesehatan terkait dengan perilaku hidup bersih dan sehat masih perlu diperhatikan. Jamban merupakan sanitasi dasar penting yang harus dimiliki setiap sekolah. Pentingnya buang air besar di jamban yang bersih untuk menghindari dari berbagai jenis penyakit yang timbul karena sanitasi yang buruk. Oleh karena itu jamban harus mengikuti standar pembuatan jamban yang sehat saluran pembuangan udara agar tidak mencemari lingkungan sekitar (Proverawati \& Rahmawati, 2012).

Indikator keempat yaitu perilaku olahraga yang teratur dan terukur menunjukkan sebagian besar siswa/siswi sudah berperilaku baik dalam olahraga yang teratur dan terukur, dan hampir setengahnya siswa/siswi masih berperilaku buruk dalam olahraga teratur dan terukur. Siswa/siswi sudah memiliki perilaku baik terhadap olahraga yang teratur dan terukur. Kegiatan olahraga sudah masuk ke jadwal pelajaran di sekolah sehingga semua siswa/siswi wajib untuk mengikuti olahraga setiap jadwal yang sudah ditentukan. Olahraga adalah suatu bentuk aktivitas fisik yang terencana dan terstruktur, yang melibatkan gerakan tubuh berulang-ulang dan ditujukan untuk meningkatkan kebugaran jasmani. Olahraga merupakan serangkaian gerak raga yang teratur dan terencana untuk memelihara gerak dan meningkatakan keampuan gerak (Depkes RI, 2010). Aktifitas fisik ini juga ditunjang dengan adanya kelas olahraga, PHBS dalam olahraga dan aktivitas fisik ini akan membantu responden dalam mencegah obesitas di usia dini dan menjaga responden untuk tetap sehat.

Indikator kelima yaitu perilaku memberantas jentik nyamuk menunjukkan bahwa sebagian besar siswa/siswi sudah berperilaku baik dalam memberanas jentik nyamuk, dan hampir setengahnya siswa/siswi masih berperilaku buruk dalam memberantas jentik nyamuk. Pemberantasan jentik nyamuk sudah menjadi program puskesmas, yang sudah di umumkan ke setiap sekolah termasuk. Pelaksanaanya pada sudah dilakukan dengan baik karena guru-guru selalu menginformasikan terkait pentingnya pemberantasan jentik nyamuk. Hal ini sejalan dengan penelitian yang dilakukan Rismawan, Anggraeni, dan Kasmini (2018) yang menunjukkan bahwa perilaku dikategorikan baik pada sebagian besar siswa/siswi yaitu sebanyak $68,3 \%$ dalam perilaku memberantas jentik nyamuk di lingkungan sekolah dikarenakan pendidikan tentang $3 \mathrm{M}$ Plus dan pemberantasan sarang nyamuk secara rutin sudah berjalan dengan baik. PHBS tentang pemberantasan sarang nyamuk di sekolah ini harus terus dimotivasi agar lebih banyak yang melakukan secara rutin. Depkes RI (2010) sendiri untuk menangani hal ini telah mengeluarkan petunjuk teknis dan pemberantasan sarang nyamuk anak sekolah yang bertujuan untuk meningkatkan peran serta anak sekolah untuk menjadi jumantik dalam pelaksanaan pemberantasan sarang nyamuk di sekolah. Memberatas jentik nyamuk di sekolah adalah kegiatan memeriksa tempat-tempat penampungan air bersih yang ada di sekolah (bak mandi, kolam, dll) apakah bebas dari jentik nyamuk atau tidak.

Indikator keenam yaitu perilaku tidak merokok di sekolah menunjukkan bahwa sebagian besar siswa/siswi sudah berperilaku 
baik yaitu tidak merokok di lingkungan sekolah, dan hampir setengahnya siswa/siswi masih berperlaku buruk yaitu merokok di lingkungan sekolah. Siswa/siswi sudah memiliki perilaku baik terhadap indikator tidak merokok di sekolah. Sudah ditentukan di sekolah tentang larangan merokok. Sanksi diberlakukan bagi siswa/siswi yang melanggar atau katahuan merokok di lingkungan sekolah. Perilaku tidak merokok di sekolah dikatakan baik dikarenakan sudah mendapatkan penyuluhan tentang bahaya merokok, maka penyuluhan harus terus dilakukan dengan harapan bahwa semakin banyak paparan informasi dengan itensitas yang tinggi membuat perilaku responden dapat drubah dalam hal PHBS tidak merokok dikelas. Rokok ibarat pabrik bahan kimia dalam satu batang rokok yang diisap akan dikeluarkan 4,000 bahan kimia berbahaya adalah Nikotin, tar dan $\mathrm{CO}$ (Depkes RI, 2010). Pengawasan orang tua dan guru yang ketat sangat dibutuhkan dalam hal ini, perkembangan teknologi dan pergaulan yang sangat pesat dapat menjadi faktor pemicu adanya perokok di usia muda.

Indikator ketujuh yaitu perilaku menimbang berat badan dan mengukur tinggi badan menunjukkan bahwa hampir seluruhnya siswa/siswi sudah berperilaku baik dalam menimbang berat badan dan mengukur tinggi badan, dan sebagian kecil siswa/siswi masih berperilaku buruk dalam menimbang berat badan dan mengukur tinggi badan. Siswa/siswi sudah memiliki perilaku baik terhadap indikator menimbang berat badan dan mengukur tinggi badan di sekolah. Indikator ini sudah menjadi program puskesmas, tujuan program ini untuk mengetahui perkembangan anak setiap bulannya sehingga dilakukan oleh pihak puskesmas untuk mengumumkan pentingnya pertumbuhan dan perkembangan anak. Kegiatan menimbang BB dan mengukur TB pada siswa/siswi dilakukan dengan tujuan untuk mentaati tingkat pertumbhan pada siswa. Hasil pengukuran dan penimbangan berat badan pada siswa/siswi tersebut dibandingkan dengan standar berat badan dan tinggi badan yang telah di tetapkan sehingga guru mengetahui pertumbuhan siswanya normal atau tidak nrmal (Evayanti, 2012). Mengukur berat badan dan tinggi badan merupakan salah satu upaya untuk mengetahui pertumbuhan dan perkembangan anak, dengan diketahuinya tingkat pertumbuhan dan perkembangan anak maka dapat memberikan masukan untuk peningkatan konsumsi makanan yang bergizi bagi pertumbuhan anak. Sedangkan untuk mengetahui pertumbuhan seorang anak normla atau tidak, bisa diketahui melalui cara membandingkan ukuran tubuh anak yang bersangkutan dengan ukuran tubuh anak sesuai pada umumnya (Depkes RI, 2010).

Indikator kedelapan yaitu perilaku membuang sampah pada tempatnya menunjukkan bahwa sebagian besar siswa/siswi sudah berperilaku baik dalam membuang sampah pada tempatnya, dan hampir setengahnya siswa/siswi masih berperilaku buruk dalam membuang sampah pada tempatnya. Siswa/siswi sudah memiliki perilaku baik terhadap indikator membuang sampah pada tempatnya. Sekolah sudah menyediakan tempat sampah di setia depan kelas dan juga sudah ada peraturan dari pihak sekolah untuk memberikan sanksi pada siswa/siswi yang membuang sampah sembarangan. Hal ini sejalan dengan penelitian yang dilakukan Wokas, Sulastri, dan Kartinah (2018), yang menunjukkan bahwa PHBS dikategorikan baik sebesar $71,1 \%$, dalam perilaku membuang sampah pada tempatnya dikarenakan pola pikir siswa terhadap penerapan perilaku membuang sampah pada tempatnya masih kurang sehingga siswa cenderung melakukannya. Siswa yang mempunyai perilaku yang baik belum tentu melakukan penerapan PHBS membuang sampah pada tempatnya, sebagian besar siswa mengetahui dampak yang ditimbulkan akibat membuang sampah sembarangan, akan tetapi mereka tidak mau melakukan penerapan indikator membuang sampah pada tempatnya (Raharjo \& Indarjo, 2015). Membuang sampah sembarangan adalah salah satu penyebab tidak 
seimbangnya lngkungan hidup. Agar sampah-sampah tidak mencari lingkungan maka sebaiknya membuang sampah pada tempatnya. Dapat dibedakan tempat pembuangan sampahnya, seperti sampah organik, dan sampah anorganik (Proverawati \& Rahmawati, 2012).

\section{Simpulan}

Hasil penelitian mengenai perilaku hidup bersih dan sehat di sekolah menunjukkan bahwa setengah dari responden sudah berperilaku baik dalam berperilaku hidup bersih dan sehat, dan hampir setengah responden masih berperilaku buruk dalam berperilaku hidup bersih dan sehat. Perilaku hidup bersih dan sehat di tatanan sekolah ini terdiri dari 8 indikator. Dari kedelapan indikator tersebut sudah terdapat 6 indikator yang memiliki perilaku baik tetapi harus terus dipertahankan dan diberikan penguatan baik oleh pihak sekolah maupun puskesmas yaitu perilaku menggunakan jamban bersih dan sehat, perilaku olahraga yang teratur dan terukur, perilaku memberantas jentik nyamuk, perilaku tidak merokok di sekolah, perilaku menimbang berat badan dan mengukur tinggi badan, dan perilaku membuang sampah pada tempatnya. Adapun untuk indikator perilaku mencuci tangan dengan air yang mengalir dan menggunakan sabun dan perilaku mengkonsumsi jajanan sehat siswa/siswi masih banyak yang berperilaku buruk. Hasil penelitian ini walaupun setengahnya dari responden sudah berperilaku baik tetapi masih terdapat hampir setengahnya responden yang masih berperilaku buruk sehingga harus segera ditindaklanjuti.

PHBS ini apabila perilakunya terus meburuk maka akan berdampak pada timbulnya berbagai penyakit. Lalu untuk mencegah hal ini, ada upaya di sekolah dengan adanya program UKS salah satunya dengan cara memberikan penyuluhan kesehatan tentang PHBS di sekolah serta dilakukan pengawasan oleh puskesmas untuk penerapannya. Dapat dilakukan kerjasama anatara pihak sekolah, Guru UKS dengan pihak puskesmas untuk melaksanakan perilaku hidup bersih dan sehat. Sehingga siswa/siswi yang ada disekolah mampu untuk melakukan PHBS di sekolah yang meliputi mencuci tangan, kemudian jajan sehat di kantin sekolah, menggunakan jamban bersih dan sehat, olahraga yang teratur dan terukur, memberantas jentik nyamuk, tidak merokok disekolah, menimbang berat badan dan mengukur tinggi badan setiap 6 bulan sekali, dan membuang sampah pada tempatnya. Dengan demikian program PHBS dapat dilakukan dengan cara bekerja sama dengan pihak sekolah. Puskesmas dan pihak sekolah dapat mengadakan program penyuluhan untuk mengedukasi siswa/siswi untuk hidup bersih dan sehat. Program penyulahan tentang PHBS atau praktik cuci tangan dengan baik dan benar, dapat dilakukan dengan mengontrol jajanan yang sehat di sekolah, program penimbangan $\mathrm{BB}$ dan mengukur TB setiap 6 bulan sekali, dengan mengadakan tempat sampah di setiap kelas.

\section{Referensi}

Carolina, P., Carolina, M., \& Lestari, R.M. (2016). Hubungan tingkat pengetahuan dan sumber informasi dengan penerapan perilaku hidup bersih dan sehat (PHBS) pada keluarga di Wilayah Kerja Pustu Pahandut Seberang Kota Palangka Raya tahun 2016. EnviroScienteae, 12(3), 330-337.

Departemen Kesehatan Republik Indonesia (2010). Pedoman PHBS tatanan sekolah. Jakarta: Departemen Kesehatan Republik Indonesia.

Dewi, N., Yudiernawati, A., \& Gabur, M.G.J. (2017). Hubungan perilaku hidup bersih dan sehat (PHBS) terhadap personal hygiene anak usia sekolah di SDN Tlogomas 2 Malang. Nursing News: Jurnal Ilmiah Mahasiswa Keperawatan, 2(1).

Evayanti, N.P. (2012). Persepsi siswa SMP 
dalam penerapan PHBS tatanan sekolah di Kelurahan Tugu dan Pasir Gunung Selatan Kota Depok. Tesis. Program Studi Magister Ilmu Keperawatan, Fakultas Ilmu Keperawatan, Universitas Indonesia, Depok, Indonesia.

Fahruzi, Z.A. (2017). Efektifitas metode ceramah dan diskusi terhadap peningkatan pengetahuan anak kelas IV tentang cuci tangan pakai sabun di SDN 044 Pekanbaru. Jurnal Kesehatan Komunitas, 3(4), 159-163.

Ispriantari, A., Priasmoro, D.P., \& Mashitah, M.W. (2019). The quality of life of adolescents with type 1 diabetes in Malang. Jurnal Ners dan Kebidanan (Journal of Ners and Midwifery), 6(1), 001-005.

Lina, H.P. (2017). Perilaku hidup bersih dan sehat (PHBS) siswa di SDN 42 Korong Gadang Kecamatan Kuranji Padang. Jurnal Promkes, 4(1), 92103.

Lolowang, M.A., Maramis, F.R., \& Ratag, B.T. (2017). Gambaran perilaku hidup bersih dan sehat di Sekolah Dasar Inpres Talikuran Kecamatan Kawangkoan Utara. Media Kesehatan, 9(3).

Lumongga, N., \& Syahrial, E. (2013). Pengaruh penyuluhan dengan metode ceramah dan diskusi terhadap peningkatan pengetahuan dan sikap anak tentang PHBS di Sekolah Dasar Negeri 065014 Kelurahan Namogajah Kecamatan Medan Tuntungan tahun 2013. Kebijakan, Promosi Kesehatan dan Biostatistika, 2(1).

Messakh, S.T., Purnawati, S.S., dan Panuntun, B. (2019). Gambaran perilaku hidup bersih dan sehat siswa Sekolah Dasar Negeri di Kecamatan
Bancak. Jurnal Ilmu Keperawatan dan Kebidanan, 10(1), 136-145.

Notoatmodjo, S. (2010). Ilmu perilaku kesehatan. Jakarta: Rineka Cipta.

Notoatmodjo, S. (2014). Kesehatan masyarakat ilmu dan seni. Jakarta: Rineka Cipta.

Paulik, E., Boka, F., Kertesz, A., \& Balogh, H. (2014). Determinants of healthpromoting lifestyle behaviour in the rural areas of Hungary. Health Promotion International, 25(3), 277288. doi: 10.1093/heapro/daq025 ISSN 1460-2245.

Peraturan Menteri Kesehatan Republik Indonesia Nomor 2269/MENKES/PER/XI/2011 tentang Pedoman Pembinaan Perilaku Hidup Bersih dan Sehat.

Proverawati, A., \& Rahmawati, E. (2012). Perilaku hidup bersih dan sehat (PHBS). Jakarta: Nuha Medika

Raharjo, A.S., \& Indarjo, S. (2015). Hubungan antara pengetahuan, sikap, dan ketersediaan fasilitas di sekolah dalam penerapan PHBS membuang sampah pada tempatnya. Unnes Journal of Public Health, 1-11 ISSN 225-6528.

Rahayu A.S, Muhlisin, A., \& Sudaryanto, A. (2016). Hubungan perawatan botol susu dan perilaku mencuci tangan dengan kejadian diare pada batita di Wilayah Kerja Puskesmas Delanggu. Diakses dari: eprints.ums.ac.id/42539/. Pada tanggal 20 Desember 2017.

Rismawan, M., Anggaraeni, R.T., \& Kasmini, K.P. (2018). Pelaksanaan program perilaku hidup bersih dan sehat (PHBS) pada SDN di Kota 
Denpasar. Jurnal Riset Kesehatan Nasional, 2(1), 71-80.

Ronosulistyo, H., \& Ina, R. (2009). Dialog keluarga menuju surga. Grasindo.

Sholikhah, H.H., \& Sustini, F. (2013). Gambaran perilaku hidup bersih dan sehat tentang foodborne disease pada anak sekolah di SDN Babat Jerawat I Kecamatan Pakal Kota Surabaya. Buletin Penelitian Sistem Kesehatan, 16(4), 351-362.

Simbolon, P., \& Simorangkir, L. (2018). Penerapan UKS dengan PHBS di wilayah kerja Puskesmas Pancur Batu Kabupaten Deli Serdang. Jurnal Kesehatan Lingkungan Indonesia, 17(1), 16-25.

Sondakh, Joseph, \& Koem, Z.A. (2015). Hubungan antara pengetahuan dan sikap dengan perilaku hidup bersih dan sehat (PHBS) pada pelajar di SD Inpres Sukur Kecamatan Airmadidi Kabupaten Minahasa Utara. PHARMACON, 4(4).

Sulastri, K., Purna, I.N., \& Suyasa, I.N. (2013). Hubungan tingkat pengetahuan dengan perilaku anak sekolah tentang hidup bersih dan sehat di Sekolah Dasar Negeri Wilayah Puskesmas Selemadeg Timur II. Jurnal Kesehatan Lingkungan, 4, 99-106.

Wokas, A., Sulastri, S.K., \& Kartinah, S.K. (2018). Gambaran tentang perilaku hidup bersih dan sehat di Sekolah Dasar Negeri Gumpang 01 Kartasura Sukoharjo. Doctoral dissertation. Universitas Muhammadiyah, Surakarta.

Yulianti, W. (2015). Pengetahuan dan perilaku hidup bersih dan sehat (PHBS) di tatanan sekolah pada anak sekolah dasar di SDN Jabon 1 Mojoanyar Mojokerto. KTI D3 Keperawatan. 